International Research Journal of Management, IT \& Social Sciences
Available online at https://sloap.org/journals/index.php/irjmis/
Vol. 5 No. 4, July 2018, pages: 53 60
ISSN: 2395-7492
https://doi.org/10.21744/irjmis.v5n4.260

\title{
Government Role in Development of Child-Friendly City based on Traditional Games
}

Marsia Sumule Genggong a

Ashmarita $^{b}$

\section{Article history:}

Received: 20 February 2018

Revised: 25 June 2018

Approved: 1 July 2018

Published: 12 July 2018

\section{Keywords:}

Task Force;

Modern Games;

Government Role;

Traditional Games;

Child-Friendly City;

\begin{abstract}
The purpose of this study is to synergize and integrate theoretical-conceptual with the development of a child-friendly city (CFC) related to the community, local elites and the government of Kendari city. It is also intended to explore the values that exist in children's traditional games in the area of Kendari city with the empirical reality that occurs during the process of urban development. This research is descriptive qualitative. Data collection technique used indepth interviews and field observations. The results show that children's traditional games in Kendari city today tend to experience a shift towards modern games based on computer and television technology. This condition affects the behavior and character of children. Children easily give up, unable to cooperate, difficult to interact with the environment are some negative impact of the modern games. Support and cooperation from various parties are needed to overcome this problem. Development of CFC is a government priority program. The CFC provides guarantees for the fulfillment of the children rights. To realize a CFC, the government should prepare the children's creative space, cooperate with the relevant parties, and form a task force for CFC. The results of the research can be used as a recommendation in the form of regulations and policies of Kendari city government toward the development of CFC through children's traditional games approach.
\end{abstract}

2395-7492@ Copyright 2018. The Author. This is an open-access article under the CC BY-SA license (https://creativecommons.org/licenses/by-sa/4.0/) All rights reserved.

\section{Author correspondence:}

Marsia Sumule Genggong,

Department of Communication

Universitas Halu Oleo, Kendari-Indonesia,

Email address: marsiasumule@yahoo.com

\section{Introduction}

The city government provides public facilities and infrastructure as a place of entertainment and education for the whole community. Children in urban areas become the center of attention because they are the young generation who

\footnotetext{
${ }^{\text {a }}$ Department of Communication, Universitas Halu Oleo, Kendari, Indonesia

${ }^{\mathrm{b}}$ Department of Anthropology, Universitas Halu Oleo, Kendari, Indonesia
} 
will inherit the noble values of the nation of Indonesia. Entertainment facilities can also be used as a tool or a place to educate children, therefore these facilities and infrastructure must really be selective

The traditional game is one of the answers to overcome the rapid modernization in the field of education and entertainment. Traditional games have noble values that become the basic character of the Indonesian people. Traditional games have a tough challenge as the development of advanced gaming technology. The tendency for modern games and the lack of interest of children against traditional games are evidence that there has been a shift in the selection of child entertainment and games in urban areas.

Research shows that in the 1980s, about 20-30 kinds of traditional games are commonly played by children in Southeast Sulawesi, but today only about 10-15 types of traditional games are known and commonly played by children. Traditional games that are still commonly played by children include marbles, engklek atau kengkeng, segitiga, ular naga, wayang, benteng, enggo sembunyi, ampar-ampar pisang, mobil-mobilan, kasti, kites, lompat tali, sadokoro, and katto-katto.

Traditional games still played by children in Kendari city can be grouped into two types of games, namely: (1) Using tools such as kelereng, kengkeng, segitiga, wayang, mobil-mobilan, kasti, layangan, lompat tali, sadokoro, and katto-katto. (2) Without tools such as ular naga and ampar-ampar pisang. Traditional games that do not use tools are usually played in groups while traditional games that use tools tend to be played individually and some are in groups. Traditional games that use tools usually have a certain time or season, so this type of game is very dependent on its season. The tools used to play are generally factory-made such as marbles, wayang, and rubber bands. The Toy is usually still kept by children so that if the season or play time arrives then the toy can be reused. Traditional games that use factory-made tools tend to be durable and can be used repeatedly as long as they are properly maintained.

Games without tools are usually played in groups. This game is competition between two or more groups. This game does not depend on the season of the game but is determined by the passion and number of children who will play at a certain moment. The more children gathered, the more likely it is to play. Games without tools increase teamwork so that will create strong interaction and foster the spirit of sportsmanship in children. Games without tools usually require a lot of movement and bodywork, such as running, squatting and jumping, so this game provides additional benefits, namely sports. Game of the castle, dragon, and snake are some types of games in this category. Benteng, ular naga and kengkeng are the game in this category.

Traditional games can train children's artistic skills, such as ampar-ampar pisang and ular naga. Playing with the singing makes the game even more interesting because of the lyrics of songs that support the game. Other traditional games such as segitiga, galasing, enggo sembunyi and benteng can educate children to create strategies to get and keep their belongings. There are many more traditional games that provide excellent benefits for moral development and the attitude of children so that later they can become individuals who are good behavior, praised, creative, initiative and high innovation

Walgito, B. (1980), the traditional game has a very important role in the character formation of children. To support the growth of children, a friendly environment is needed, where children can grow and develop properly based on their age. The role of government and society are crucial in realizing the CFC where traditional games are used as a means of characterizing the child's character. This research discusses the role and support of the government in developing CFC based on cultural communication in perspective of children's traditional games in Kendari city.

\section{Research Methods}

This research is conducted by using the qualitative descriptive method with ethnography study. A qualitative approach is a kind of contextual research that makes man the main instrument (instrument law) and adapted to the natural setting. Suiraoka, I. P., Duarsa, D. P. P., Wirawan, I. D. N., \& Bakta, I. M. (2017), Susanti, F., Siswati, S., \& Widodo, P. B. (2010), qualitative approach is descriptive to gain a deeper picture and a holistic understanding based on the natural setting of the case to be studied.

\subsection{Location}

The research is conducted on 5 (five) districts in Kendari, namely: Kendari, Kendari Barat, Mandonga, Poasia, and Baruga. The selection of those locations is based on the consideration of the distribution of the residents especially children in those of five areas. 


\subsection{Informant}

Informants in this study were determined by purposive sampling consisting of key informants and ordinary informants. Informants consist of local government, educational institutions, kindergarten teachers, BKKBN (family planning and population control department), Puskesmas (community health centers), cultural park department and Museum of Kendari city.

\subsection{Data collection technique}

Data collection methods used in this research are participant observation, interview, and library research methods.

a) Observation participation

Observation Participants is conducted by involving themselves directly on the object of research, in this case, the community in the family, especially children, playground, children activities while playing and types of games. Participatory observation has a broader meaning than just a post-participative observation, ie research activities, field research, field studies, field work, or name in various other titles.

b) Interview

The interview is conducted by asking questions of all informants. Pemayun, A. G. P., \& Maheswari, A. I. A. (2017), the tools needed in this in-depth interview are interview guides, notebooks, and tape recorders. the interview atmosphere is organized in a dialogical form, so the theme of the conversation can be more developed, and there is an opportunity to repeat a question. The selection of interview techniques is based on the advantages of the technique itself, which can enter the world of thoughts and feelings of the informants. Interview topics are local curriculum content, traditional game values, traditional game types taught in schools, NGOs involvement in addressing child issues, parental control of children, child-friendly public facilities and policy recommendations in the development of child-friendly cities.

\subsection{Data analysis technique}

Galba, S., \& Manan, R. (1991), data analysis is done descriptively qualitative by describing the research result by description to answer the problem. The analysis is done by compiling the data obtained, then interpreted by referring to the interrelationship between the various concepts and the reality that exists in the field. The data collected, then grouped according to their parts. Hadi, A., Handajani, L., \& Putra, I. N. N. A. (2018), showed that by conducting continuous data analysis, the researcher will get the whole reasoning about the result of the research which is achieved from the problem studied.

This study uses qualitative data analysis techniques that describe and analyze the picture or thematic text obtained from interviews, observations and focused group discussions (FGD). Howe, C. (2009), qualitative data analysis is used to analyze the first and second research questions, by classifying the data obtained, then analyzed in accordance with the symptoms or objects that are studied and interpreted based on existing theory. This data analysis is done continuously throughout this research. Continuous data analysis provides an opportunity for researchers to carefully and thoroughly collect and assess the data required. Mönks, F. J., Knoers, A. M. P., \& Haditono, S. R. (1985), Mpofu, E., Thomas, K. R., \& Chan, F. (2004), if there is still data required, then a new strategy can be developed to obtain the data in a short time.

\section{Results and Analysis}

\section{Government Role in Supporting the CFC}

The traditional game is an inseparable part of Indonesian culture that is very rich with various ancestral heritage cultures with a variety of traditional games. Traditional games teach children to be creative and innovative. In addition to the game required supporting facilities and infrastructure, so that children can enjoy the game.

Nowadays, the traditional game is rarely played. To maintain the existence of traditional games, society has a very important role because the community is the main perpetrator of the traditional game. In addition, government support is also crucial, because, in order to regenerate traditional games in the community, it is necessary to support facilities and infrastructure that support the activities.

Genggong, M. S., \& Ashmarita, -. (2018). Government role in development of child-friendly city based on traditional games. International Research Journal of Management, IT and Social Sciences, 5(4), 53-60. 
Traditional games are no longer a popular game for kids. Nowadays, most kids prefer the modern game. Modern games can have a negative impact on children if not played proportionately. On the other hand, traditional games that are ancestral heritage can be abandoned, even forgotten by children. The existence of traditional games in society requires the support of the government, society and other related parties so that traditional games will continue to grow and develop into the next generation. The role of the Kendari City government in supporting and developing traditional game-based CFC involves cooperation with stakeholder, infrastructure development, and task force formation for CFC

\subsection{Cooperation with related parties}

The government of Kendari city can work together with various parties to support the CFC, such as family planning and population control department and educational institutions.

a) Family planning and population control departments.

Family planning and population control department of Kendari make a great contribution in supporting CFC programs. Family planning and population control department is responsible for resolving population issues through programs such as Bina Keluarga Balita (BKB), Bina Keluarga Remaja (BKR) and Bina Keluarga Lansia (BKL).

Kendari City Government seeks to increase stakeholder participation to realize CFCs. CFC workshops and advocacy are held regularly by involving all stakeholders. The workshop is a place to discuss how to handle the problems of children. Through this forum, all stakeholders who are members of the task force emphasized the commitment to realize the 31 rights of children. In addition, coaching is also performed to help cadres socialize family planning and population control departments programs in the community. The number of cadres that have been scouted is 70 people. The cadres are located in various locations in Kendari city. Youth coaching at school is performed through Bina Keluarga Remaja (BKR) program. In addition, there is also a center for information and counseling for teenagers who work with Guru BK (teachers Counseling Guidance).

b) Community health centers (Puskesmas)

Dharmamulja, S. (2004), one of the basic rights of the people is the right to obtain adequate health services. The right to adequate health care is guaranteed in the constitution of the Republic of Indonesia and in the United Nations human rights declaration. To ensure affordable health services to remote villages, the government has built various health services, such as hospitals, Puskesmas and Posyandu (integrated health care posts). One of the health services that has been built by the government of Kendari city is Puskesmas Mekar Kendari. Puskesmas Mekar was originally a subsidiary of Puskesmas Perumnas. Puskesmas Mekar was officially opened on June 6, 2005, to optimize the health service function in the community. The Puskesmas Mekar service is dedicated to mothers, children, labor and low-income communities both in rural and urban areas. Puskesmas became the center of health development in their respective working areas. The development of health services to the community is performed through the following steps:

1) Extending health services to villages by establishing Puskesmas Pembantu (subsidiary Puskesmas), Pos Kesehatan, Posyandu, and placement of midwives in villages managing a Polindes (Village Birth Policlinic).

2) Improving the quality of health services by improving the skills and motivation of the staff and improving the quality of equipment and medicines.

3) Procurement of equipment and medicines that meet the needs of the community. Planning is based on an epidemiological analysis of the disease that develops in the working area of the Puskesmas.

4) Referral systems at the primary health care level are strengthened by improving the quality of health services down to the village level. Development of other sectors also needs to be considered, such as the availability of more adequate transportation facilities and increased family income.

5) Community participation through the expansion of Village Community Health Development. This activity needs to be done through mutual cooperation and self-help so that people are able to achieve a healthy and prosperous quality of life.

c) Educational institution

Traditional games need to be conserved. They have a positive impact on child development. Children are the next generation of the nation. In addition, the traditional game is a legacy of the nation's ancestors. The responsibility of youth coaching is not only the responsibility of the government, but other institutions need to be 
involved especially educational institutions. Primary school, kindergarten, and Early Childhood Education institutions need to be involved in CFC programs. They are formal institutions, where children get the basic education. School is an important component of learning, where children learn and interact with their friends. The school environment is expected to have a significant effect on the children's development. Teachers are an important element in the learning process in the school. Teachers are expected to be the backbone in the fulfillment of the rights of children in school. In addition, teachers can be a pioneer in introducing traditional games to children early on.

Chalpin, J. P. (2006), traditional games have been taught to children in schools, especially in early childhood and kindergarten. This game is taught in each class and adapted to the curriculum that has been previously compiled. For example, in TK Mu'adz Bin Jabal, the introduction of traditional games is performed at the 3rd week of the first semester. In addition, towards the end of the semester, there is a traditional children's game competition conducted between classes. TK Mu'adz Bin Jabal is an Islamic school. In TK Mu'adz Bin Jabal, children are taught religious values, morals as well as games that stimulate the cognitive and physical aspects of the child's motor. For the cognitive aspect, children are told to record and count the number of images. The origami game, college, and cardboard forming objects are examples of activities to stimulate children's creativity. Schools also prepare congklak, bola bekel, lego, and others.

\subsection{Space for the creativity of children}

Children need to improve their creativity, therefore, the government has set up space where children can improve their creativity.

a) Cultural park

Sulawesi Tenggara cultural park is one of the Regional Technical Service Unit (UPTD) in the field of culture. Cultural Park serves to foster and develop various assets of culture and local art. Cultural Park has the same position with museums, regional library, tourism, and dekranasda (regional national people's arts council). Sulawesi Tenggara cultural park serves as a laboratory in managing various local arts activities. The Sulawesi Tenggara cultural park program such as festivals, competitions, and workshops, has provided significant benefits for the development of local arts and culture.

Baron, R. A., \& Byrne, D. E. (1984), various kinds of traditional games are well documented in museums that are part of the Cultural Park. Cultural parks support the revitalization of traditional games, because traditional games have positive values. The revitalization of traditional games is done through various programs that are conducted regularly. Museum visit programs, exhibitions, and traditional game competitions are conducted regularly. The exhibition program and museum visit are open to the public. Through this program, children can learn about a variety of traditional games that may have been rarely played, even they can try to play the game. Traditional game contests are also held regularly every year as a form of socializing traditional games to the community.

Ariani, C. (1998), the programs are undertaken by cultural parks and museums are to remind people of traditional games as an ancestral cultural heritage. The revitalization of traditional games to the community in addition to reinvigorating the positive values contained in the traditional game, as well as to reduce the negative impact of modern gadget-based games.

Traditional games also contain many meanings and can even build positive characters in children. Unfortunately, traditional games are no longer known, displaced by modern games that rely on technology. Today's parents probably do not remember traditional games anymore, not even knowing them. If parents do not know traditional games, then they are impossible to teach it to their children.

Cultural parks are ready to receive children's visits for recreation and study. They will be taught about art and culture. Cultural parks recommend introducing culture to children at an early age.

b) Museum

Kendari city has various tourism potentials, such as culinary, cultural and historical tourism. Old city sites and museums are historical sites that can be visited. Museum of Kendari city has many kinds of special collections. The museum collections are divided into 10 collections space: Geologika, Biologika, Etnografi, Arkeologi, Historika, Numismatic, ceramic room, traditional art and Teknologika collection.

Genggong, M. S., \& Ashmarita, -. (2018). Government role in development of child-friendly city based on traditional games. International Research Journal of Management, IT and Social Sciences, 5(4), 53-60. 
The geologika chamber holds various types of rocks and a replica of a nickel mine. The Biologika room houses a collection of preserved Sulawesi-typical animals. The Etnografi room stores various collections of traditional clothing, woven-typical Kendari fabrics, looms, household appliances, agricultural equipment, and hunting equipment. The Arkeologi room contains various replicas of fossils, stones (ancient human equipment), and pottery. The Historika room stores a collection of photographs of the kingdom of Buton, photographs of national heroes, and photos of Sulawesi Tenggara governor's officials. Numismatic collection room, store various collections of currencies of various kingdoms in the past. The Filologika chamber keeps the manuscripts of lontara, katakanari, tasbih, handwriting of Al-Qur'an, amarana script, and khatib stick. The Keramik room store a variety of ceramic collections. Most of the ceramics collection in the museum comes from the Chinese dynasty. The traditional art collection room keeps a variety of local art gear such as gambus, gong, and flute. The Teknologika room keeps a collection of technologies, such as newspaper printing machines, telegram machines, rice pounders, sago processing tools and other historical objects.

The Museum of Kendari city held workshops and exhibitions to promote traditional games to the young generation. The museum has been set up a special place for the improvement of creativity and children's playground behind the museum building. The museum has introduced traditional games to schools. The traditional game contest is also held at the junior high school culture competition. The museum invites students to visit museums. At the visit time, the museum provides socialization about the cultural collections in the museum. To attract visitors, the museum provides a gift to schools that make the most visits. Socialization is also performed by visiting schools, especially schools that are far away from the city. Cultural competitions are organized by museum regularly every year. The winner will represent Sulawesi Tenggara to the national level.

\subsection{CFC task force}

The CFC task force was established by the government and other parties to develop CFC. Kendari city Government is optimistic to defend the CFC madya category this year. The task force was formed to finalize the preparedness of the city in the face of the central government assessment. Members of the CFC task force are the relevant department, such as the Women's Empowerment and Child Protection Department, Population Control and Family Planning Department and child NGOs. The CFC task force membership is 5 years.

\section{Conclusion}

Nowadays, children's traditional games in Kendari city tend to experience a shift towards modern games based on computer and television technology. The effect of this shift is the change in behavior and character of the child. Easily to give up, unable to cooperate and interact with others are the example of the negative effects of the modern game. CFC as a government program needs to get support from various parties. CFC ensure the fulfillment of children's rights, including the right to play and receive an education. The traditional game is an ancestral heritage that needs to be revitalized. The traditional game contains positive values that are appropriate for the development and character building of the child. The role of government in the revitalization of children's traditional games through the CFC program is very important. The provision of child creativity facilities, the establishment of special task forces and cooperation with various parties need to be performed to support Kendari as a child-friendly city.

\section{Conflict of interest statement and funding sources}

The authors declared that they have no competing interest. The study was financed by independent funding.

\section{Statement of authorship}

The authors have a responsibility for the conception and design of the study. The authors have approved the final article.

\section{Acknowledgments}

The authors would like to express the appreciation to The Ministry of Research Technology and The Higher Education Republic of Indonesia for supporting this work through Hibah Penelitian Produk Terapan Batch II. 


\section{References}

Ariani, C. (1998). Pembinaan Nilai Budaya Melalui Permainan Rakyat Daerah Istimewa Yogyakarta. Yogyakarta: Depdikbud, Dirjen Kebudayaan, Direktorat Sejarah dan Nilai Tradisional.

Baron, R. A., \& Byrne, D. E. (1984). Social psychology: Understanding human interaction. Allyn \& Bacon.

Chalpin, J. P. (2006). Kamus Lengkap Psikologi (Terjemahan Kartini Kartono). Jakarta. PT Radja Grafindo Persada.

Dharmamulja, S. (2004). Permainan Tradisional Jawa. Kepel Press.

Galba, S., \& Manan, R. (1991). Pesantren sebagai wadah komunikasi. Departemen Pendidikan dan Kebudayaan, Direktorat Jenderal Kebudayaan, Direktorat Sejarah dan Nilai Tradisional, Proyek Inventarisasi dan Pembinaan Nilai-Nilai Budaya.

Hadi, A., Handajani, L., \& Putra, I. N. N. A. (2018). Financial Disclosure based on Web-ICT Determinants: Its Implications for Local Government Financial Performance in Indonesia. International Research Journal of Management, IT and Social Sciences (IRJMIS), 5(1), 72-85.

Howe, C. (2009). Peer groups and children's development(Vol. 14). John Wiley \& Sons.

Mönks, F. J., Knoers, A. M. P., \& Haditono, S. R. (1985). Psikologi Perkembangan: Pengantar dalam berbagai bagiannya. Gadjah Mada UP.

Mpofu, E., Thomas, K. R., \& Chan, F. (2004). Social competence in Zimbabwean multicultural schools: Effects of ethnic and gender differences. International Journal of Psychology, 39(3), 169-178.

Pemayun, A. G. P., \& Maheswari, A. I. A. (2017). Economic Impacts of Craftsman Statue on Community Based Tourism Development. International Journal of Social Sciences and Humanities (IJSSH), 1(3), 59-73.

Suiraoka, I. P., Duarsa, D. P. P., Wirawan, I. D. N., \& Bakta, I. M. (2017). Perception of Parents, Teachers, and Nutritionist on Childhood Obesity and Barriers to Healthy Behavior: A Phenomenological Study. International Journal of Health Sciences (IJHS), 1(2), 1-11.

Susanti, F., Siswati, S., \& Widodo, P. B. (2010). Pengaruh Permainan Tradisonal Terhadap Kompetensi Interpersonal Dengan Teman Sebaya Pada Siswa SD (Studi Eksperimental Pada Siswa Kelas 3 Sdn Srondol Wetan 04-09 Dan Sdn Srondol Wetan 05-08). Jurnal Psikologi, 8(2), 145-155.

Walgito, B. (1980). Psikologi sosial: Suatu pengantar. Fakultas Psikologi UGM.

Genggong, M. S., \& Ashmarita, -. (2018). Government role in development of child-friendly city based on traditional games. International Research Journal of Management, IT and Social Sciences, 5(4), 53-60. 


\section{Biography of Authors}

\begin{tabular}{|l|l|l|} 
Marsia Sumule Genggong \\
Department of Communication, Universitas Halu Oleo, Kendari, Indonesia
\end{tabular}

